\title{
Constitutional Court of the Russian Federation, Decision from 19 April 2016, No. 12-P/16. An Assessment from a German Point of View
}

\author{
Julia Haak* \\ University Passau Innstraße \\ 41 Passau, 94032, Germany
}

Received 20.04.2017, received in revised form 02.06.2017, accepted 08.06.2017

\begin{abstract}
The constitutional decision from 19 April 2016, No. 12-P/16 was the first case in connection with a request concerning the implementation of decisions from the Strasbourg Court in the Russian Federation. It has its roots in the right to vote for prisoners, which is expressly prohibited in Article 32(3) of the Russian Constitution. In its decision from 4 July 2013, the European Court of Human Rights found this regulation to be illegal with regard to Article 3 of the Protocol to the European Convention on Human Rights in the case "Anchugov and Gladkov". The Russian Constitutional Court considered that the national implementation of this decision it not possible and based this conclusion mainly on the status of the Russian Constitution above the European Convention on Human Rights. It is needful to shed light on the measures the Strasbourg Court considered necessary and to assume if an implementation in the Russian Federation would be really impossible in this regard, as stated by the Russian Constitutional Court.
\end{abstract}

Keywords: European Convention on Human Rights, European Court of Human Rights, Constitution of the Russian Federation, Constitutional Court of the Russian Federation, prohibition on the right to vote, implementation measures.

DOI: 10.17516/1997-1370-0091.

Research area: law.

After the constitutional decision in the case $21-\mathrm{P} / 15$ dated July $14,2015^{1}$, the Russian Constitutional Court Act was decisively amended $^{2}$. The Russian legislature created a possibility to bring questions regarding the implementation of the decision of the Strasbourgbased European Court of Human Rights (the "ECtHR") before the Constitutional Court of the Russian Federation (the "RCC"). Shortly afterwards, the Ministry of Justice of the Russian Federation submitted a request in connection with the "Anchugov and Gladkov" case ${ }^{3}$. This decision seemed most obviously problematic, because the Constitution of the Russian Federation (the "Russian Constitution") explicitly prohibits the right to vote for prisoners, which, however, the

(C) Siberian Federal University. All rights reserved

* Corresponding author E-mail address: julia.haak@uni-passau.de 
ECtHR has found to be illegal with regard to the European Convention on Human Rights (the "ECHR").

The applicants Anchugov and Gladkov were sentenced to 15 years in prison each for serious criminal offenses such as murder, theft, heavy robbery and fraud ${ }^{4}$. According to Article 32(3) of the Russian Constitution, they were therefore automatically not allowed to participate in any elections ${ }^{5}$. They both appealed to national courts, up to the Supreme Court of the Russian Federation, but without success ${ }^{6}$. In 2004 and 2005, both of them submitted individual applications to the ECtHR in Strasbourg.

In its decision from July 4, 2013, the ECtHR found a breach of Article 3 of the Protocol to the $\mathrm{ECHR}^{7}$. According to the case-law of the ECtHR, the right to free elections is not granted in absolute terms and the High Contracting Parties have a wide margin of appreciation in connection with this regulation ${ }^{8}$. In particular, they are able to develop their own democratic vision in line with the "historical development, cultural diversity and political thought" of the country9. But finally, it is up to the ECtHR to review the chosen system for its compatibility with the ECHR ${ }^{10}$. Article 32(3) of the Russian Constitution states: "Citizens who have been declared legally incompetent by a court, as well as citizens who are found in places of deprivation of liberty on grounds of court judgments, have no right to participate and to stand as a candidate in election". Therefore, this norm refers to all convicted persons serving a prison sentence regardless of the length of their prison term, the nature or severity of the offense or the circumstances of the individual case ${ }^{11}$. Although the ECtHR recognizes the objectives pursued by this standard, such as the respect of law and order and the assurance of a democratic system, it does not affirm the compliance with the principle of proportionality ${ }^{12}$. The ECtHR also noticed that the law in question is formulated in Chapter Two of the Russian Constitution and that an amendment to this norm would require a very complicated procedure in accordance with Article 135 of the Russian Constitution ${ }^{13}$. For this reason, "it is open to the respondent Government to explore all possible ways" in order to fulfil its obligations under Article 46 of the ECHR, if a constitutional modification appears to be too complex ${ }^{14}$. In particular, at this point, a conformal interpretation of the corresponding constitutional norm by the RCC "in harmony with the Convention" might be a permissible opportunity "to coordinate their effects and avoid any conflict between them"15.

In 2008 and 2009, the applicants were released from prison, so no individual implementation measures were needed at the time of the decision of the ECtHR ${ }^{16}$. Nor did the ECtHR receive any compensation under Article 41 of the ECHR ${ }^{17}$. However, the general implementation measures, i.e. legislative changes or an interpretation consistent with the ECHR, presented a difficult challenge to Russia. Therefore, the question of implementation was submitted to the RCC. In its decision of April 19, 2016 ${ }^{18}$, the Court found the following:

1. The implementation of the ECtHRdecision is impossible with regard to the general measure of a constitutional amendment ${ }^{19}$. Article 32(3) of the Russian Constitution takes precedence and the highest legal force in the Russian legal system; it expressly imposes a mandatory prohibition on the right to vote for all convicted persons in places of deprivation of liberty ${ }^{20}$.

2. The implementation of the ECtHRdecision is possible and feasible with regard to ensuring proportionality and differentiation in the restriction of the electoral right ${ }^{21}$. This derives from the provisions of the Criminal Code of the Russian Federation (the "Russian Criminal Code"), which specify the constitutional 
standards. In addition, the federal legislature is free to optimize the penal system ${ }^{22}$.

3. The implementation of the ECtHRdecision is impossible with regard to the individual measures relating to the applicants. Since both were convicted to long prison sentences for particularly serious offenses, the right to vote could not be granted to them ${ }^{23}$, even according to the criteria of the $\mathrm{ECtHR}^{24}$. In addition, they were no longer detained at the time of the ECtHR-decision.

To justify this ruling, the RCC interpreted the contested law and finally concluded that Article 32(3) of the Russian Constitution cannot be understood in the way as proposed by the $\mathrm{ECtHR}^{25}$. It was formulated as a mandatory prohibition, without any exceptions. A restrictive, conformal interpretation is incompatible with the wording and therefore impossible ${ }^{26}$.

However, the RCC has the following proposal for a compromise: the restriction of the right to vote by the Russian Constitution results from two requirements, one concerning the criminal law, namely a sentence of imprisonment, and one concerning the criminal procedural law, namely serving the sentence in places of deprivation of liberty $^{27}$.

According to Article 56(1) of the Russian Criminal Code, "deprivation of liberty" in this sense means an isolation of the convicted person from society by being located in, for instance, criminal colonies or prisons. It therefore relates only to special custodial sanctions in contrast to other possible measures restricting freedom, such as compulsory labour in accordance with Article 44 of the Russian Criminal Code ${ }^{28}$. As a result, only deprivation of liberty within the meaning of Article 56 leads to the loss of the right to vote, not the consequences of Article 44 of the Russian Criminal Code ${ }^{29}$. In this respect, it cannot be said that there is a general and undifferentiated prohibition of the right to vote for all convicted persons ${ }^{30}$. Furthermore, several provisions in the Russian Criminal Code practically exclude the possibility that a person is sentenced to a deprivation of liberty if he or she committed a criminal offense for the first time, or merely committed a minor offense, or if there are no aggravating circumstances. In such situations, the applicability of Article 32(3) of the Russian Constitution is therefore unfeasible ${ }^{31}$. There is consequently no undifferentiation and disproportion ${ }^{32}$. Nevertheless, the federal legislature is free to provide specific correctives ${ }^{33}$.

After all, the RCC regarded the constitutional norm in the light of the provisions of the Russian Criminal Code and therefore considered the prohibition to be not general, but sufficiently differentiated and proportionate. However, the fact remains that in case of all measures of deprivation of liberty within the scope of Article 56 of the Russian Criminal Code, the consequence of Article 32(3) of the Russian Constitution follows automatically. In this respect, there is no distinction between the severity of the offense, the particular circumstances or the length of the imprisonment.

There is no prohibition of the right to vote in connection with measures restricting the liberty. But these are, however, solely restrictions in the sense of the Russian Criminal Code, not deprivations of liberty, and therefore do not create an adequate corrective within the scope of the Russian Constitution. It may also be that, de facto, no one would have to fear a prohibition due to a minor offense, because in this case deprivation of liberty in accordance with the Russian Criminal Code is not possible. This, however, does not guarantee a sufficient level of proportionality, especially with regard to such a fundamental right like the right to vote.

By reaching the verdict, the judges consider the circumstances that justify deprivation of liberty, but not those that justify deprivation of 
the right to vote. This is always the automatic consequence, without a margin of appreciation for the criminal courts. However, the necessity of prohibition of the right to vote for a defendant cannot always be inferred from the necessity of deprivation of liberty. On the contrary, the criminal courts should also deliberately deal with the consequences of Article 32(3) of the Russian Constitution on the specific circumstances of the individual case and expressly state this decision in the judgment.

For this reason, a certain statement by the $\mathrm{RCC}$ regarding a corresponding regulation for the criminal courts would be more expedient. They should be obliged to decide expressly, in addition to the deprivation of liberty, on the prohibition of the right to vote on the basis of the circumstances of the individual case. The consequence would not be an automatism between deprivation of liberty and prohibition of the right to vote, but a judicial decision in respect of the right to vote in every single case, according to the degree of the public danger of the offense or the personality of the accused person. The wording of Article 32(3) could be interpreted insofar as it would be necessary to condemn deprivation of liberty as well as an express, positive decision of the criminal court on the basis of the circumstances of the individual case for the prohibition of the right to vote. If the criminal court has not recognizably dealt with the deprivation of the right to vote or if the decision is negative in this regard, the accused person may be imprisoned, but may continue to exercise the right to vote ${ }^{34}$. This result could be achieved by amending federal laws as a concretization of the constitutional standard ${ }^{35}$.
In summary, the following can be stated: The RCC considered that the implementation of the ECtHR-decision of July 4, 2013, in the "Anchugov and Gladkov" case is not possible. This conclusion is mainly based on the status of the Russian Constitution above the ECHR and the judgments of the ECtHR. The mere tenor of the decision is convincing: the norm of a national constitution cannot be changed solely on the basis of the case-law of Strasbourg, the federal legislature is free to remedy the situation and nothing can be done for the applicants because they have already been released from custody.

The RCC expressly stated that the ECtHR cannot force Russia to change its constitution. However, such a measure has neither been called for by the ECtHR, nor is it the only way to ensure conformity with the ECHR. One possible solution would be the amendment of federal laws, which specify the corresponding constitutional standard. This approach was also seen by the RCC, but a vague recommendation to the legislature to provide remedy, is not enough. It should be noted that the ECtHR did not call for the right to vote to be granted to all sentenced prisoners or for an amendment to the Russian Constitution. The violation of the Convention consists solely of the automatic occurring prohibition of the right to vote in every conviction to a deprivation of liberty, without any differentiation. An appropriate solution would be not to deprive every condemned person of the right to vote, one of the most important fundamental rights in a democracy. This approach, which would be achieved by a corresponding amendment to the federal laws, could solve the loudly raised conflict between the Russian Constitution and the ECHR.

RCC, Judgment, 14 July 2015 - 21-P/15.

Federal Constitutional Law 'On the amendment of the Russian Constitutional Court Act' from 14 December 2014 , No. 7-FKZ.

ECtHR, Judgment, 4 July 2013, Appl. Nos. 11157/04, 15162/05. Anchugov and Gladkov v. Russia.

ECtHR, Judgment, 4 July 2013, Appl. Nos. 11157/04, 15162/05, §§ 8, 12. Anchugov and Gladkov v. Russia.

ECtHR, Judgment, 4 July 2013, Appl. Nos. 11157/04, 15162/05, §§ 15 et seq. Anchugov and Gladkov v. Russia. 
6 ECtHR, Judgment, 4 July 2013, Appl. Nos. 11157/04, 15162/05, §§ 23 et seq. Anchugov and Gladkov v. Russia.

7 ECtHR, Judgment, 4 July 2013, Appl. Nos. 11157/04, 15162/05, § 112. Anchugov and Gladkov v. Russia.

8 ECtHR, Judgment, 4 July 2013, Appl. Nos. 11157/04, 15162/05, § 95. Anchugov and Gladkov v. Russia; see also ECtHR, Judgment, 2 March 1987, Appl. No. 9267/81, § 52. Mathieu-Mohin and Clerfayt v. Belgium; ECtHR (Grand Chamber), Judgment, 18 February 1999, Appl. No. 24833/94, § 63. Matthews v. United Kingdom; ECtHR (Grand Chamber), Judgment, 6 April 2000, Appl. No. 26772/95, § 201. Labita v. Italy; ECtHR, Judgment, 1 July 1997, Appl. Nos. 18747/91 et al., $\S 39$. Gitonas et al. v. Greece; Meyer-Ladewig et al., 2017, Protocol Art. 3, § 6.

9 ECtHR, Judgment, 4 July 2013, Appl. Nos. 11157/04, 15162/05, § 95. Anchugov and Gladkov v. Russia; see also ECtHR (Grand Chamber), Judgment, 6 October 2005, Appl. No. 74025/01, § 61. Hirst (No. 2) v. United Kingdom; ECtHR (Grand Chamber), Judgment, 22 May 2012, Appl. No. 126/05, § 83. Scoppola (No. 3) v. Italy.

10 ECtHR, Judgment, 4 July 2013, Appl. Nos. 11157/04, 15162/05, § 96. Anchugov and Gladkov v. Russia.

${ }_{11}$ ECtHR, Judgment, 4 July 2013, Appl. Nos. 11157/04, 15162/05, § 101. Anchugov and Gladkov v. Russia.

12 ECtHR, Judgment, 4 July 2013, Appl. Nos. 11157/04, 15162/05, § 102. Anchugov and Gladkov v. Russia.

13 ECtHR, Judgment, 4 July 2013, Appl. Nos. 11157/04, 15162/05, §§ 108, 111. Anchugov and Gladkov v. Russia.

14 ECtHR, Judgment, 4 July 2013, Appl. Nos. 11157/04, 15162/05, § 111. Anchugov and Gladkov v. Russia.

15 ECtHR, Judgment, 4 July 2013, Appl. Nos. 11157/04, 15162/05, § 111. Anchugov and Gladkov v. Russia.

16 Committee of Ministers, 2014, Individual measures.

17 ECtHR, Judgment, 4 July 2013, Appl. Nos. 11157/04, 15162/05, § 121. Anchugov and Gladkov v. Russia.

18 RCC, Judgment, 19 April 2016. 12-P/16.

19 RCC, Judgment, 19 April 2016, Tenor § 1, p. 40 et seq. 12-P/16.

20 RCC, Judgment, 19 April 2016, Tenor $\S 1$, p. 40 et seq. 12-P/16.

${ }_{21}$ RCC, Judgment, 19 April 2016, Tenor § 2, p. 41 et seq. 12-P/16.

22 RCC, Judgment, 19 April 2016, Tenor § 2, p. 42. 12-P/16.

23 RCC, Judgment, 19 April 2016, Tenor § 3, p. 42. 12-P/16.

24 ECtHR, Judgment, 4 July 2013, Appl. Nos. 11157/04, 15162/05, § 101. Anchugov and Gladkov v. Russia.

25 RCC, Judgment, 19 April 2016, § 4.1, p. 17. 12-P/16.

26 RCC, Judgment, 19 April 2016, § 4.1, p. 17. 12-P/16.

27 RCC, Judgment, 19 April 2016, § 5.1, p. 27. 12-P/16.

28 RCC, Judgment, 19 April 2016, § 5.1, p. 28.12-P/16.

29 RCC, Judgment, 19 April 2016, § 5.1, p. 28. 12-P/16.

30 RCC, Judgment, 19 April 2016, § 5.1, p. 30. 12-P/16.

31 RCC, Judgment, 19 April 2016, § 5.2, p. 32. 12-P/16.

32 RCC, Judgment, 19 April 2016, § 5.2, p. 33. 12-P/16.

33 RCC, Judgment, 19 April 2016, § 5.5, p. 36. 12-P/16.

34 See the recommendations ofthe Institute Law and Public Policy, 2016, § 53, to withdraw the right to vote only in special cases depending on nature and severity of the offense or the duration of the prison sentence, or to introduce the deprivation of the right to vote as a special criminal sanction.

35 See also Sultanov, 2015, p. 13.

\section{References}

Appl. Nos. 11157/04, 15162/05, Anchugov and Gladkov. (2013). In European Court of Human Rights, v. Russia.

Appl. Nos. 18747/91 et al., Gitonas et al. (1997). In European Court of Human Rights, v. Greece.

Appl. No. 74025/01, Hirst (No. 2). (2005). In European Court of Human Rights, v. United Kingdom.

Appl. No. 26772/95, Labita. (2000). In European Court of Human Rights, v. Italy.

Appl. No. 9267/81, Mathieu-Mohin and Clerfayt. (1987). In European Court of Human Rights, v. Belgium.

Appl. No. 24833/94, Matthews. (1999). In European Court of Human Rights, v. United Kingdom. Appl. No. 126/05, Scoppola (No. 3). (2012). In European Court of Human Rights, v. Italy.

Committee of Ministers, Council of Europe (2014). Information document DH-DD(2014)1251 on enforcement of the Judgment of the European Court of Human Rights in case nos. 11157/04, 15162/05 Anchugov and Gladkov v. Russia (Judgment of 4 July 2013, final on 9 December 2014); available at https://rm.coe.int/CoERMPublicCommonSearchServices/DisplayDCTMContent?documentId=09000 016804a423e (last visited 15 March 2017). 
Institute Law and Public Policy. (2016). Decision on the interpretation of Article 32(3) of the Constitution of the Russian Federation for the purpose of determining the possibility of implementing the decision of the European Court of Human Rights from 4 July 2013 in the case "Anchugov and Gladkov v. the Russian Federation"; available at http://ilpp.ru/netcat_files/userfiles/Litigation Treinings/2016\%20Amicus\%20Curiae\%20Brief\%20(Anchugov\%20i\%20Gladkov).pdf (last visited 24 February 2017).

Judgment 14 July 2015, 21-P/15, In Constitutional Court of the Russian Federation.

Judgment, 19 April 2016, 12-P/16, In Constitutional Court of the Russian Federation.

Meyer-Ladewig, J., Nettesheim, M., von Raumer, S. (Eds.) (2017). In ECHR-Commentary. BadenBaden: Nomos.

Sultanov, A. (2015). Request of the deputies to the Constitutional Court of the RF against the implementation of Judgments of the European Court of Human Rights, In Legislation and Economics, 7 et seq.

\title{
Постановление Конституционного суда Российской Федерации \\ от 19 апреля 2016 г. № 12-П/16. Анализ с точки зрения Германии
}

\author{
Ю. Хаак \\ Университет Пассау \\ Германия, 94032, Пассау, Иннштрассе, 41
}

Постановление Конституционного суда от 19 апреля 2016 г. № 12-П/16 было первым случаем в связи с запросом об исполнении решений Страсбургского суда в Российской Федерации. В нем говорится о предоставлении избирательного права заключенным, прямо запрещенного статьей 32(3) Конституиии Российской Федерации. В своем постановлении от 4 июля 2013 г. Европейским судом по правам человека было установлено нарушение статьи 3 Протокола Европейской конвенции по правам человека в деле «Анчугов и Гладков против России». Российский Конституционный суд счел применение этого постановления невозможным по причине приоритета Российской конституции над Европейской конвенцией по правам человека. Представляется необходимым осветить меры, предложенные Страсбургским судом, и рассмотреть, действительно ли применение указанного постановления было настолько невозможным в данной ситуации, насколько утверждается Конституиионным судом Российской Федерации.

Ключевые слова: Европейская конвенция по правам человека, Европейский суд по правам человека, Конституичия Российской Федерации, Конститущиионный суд Российской Федераџии, лишение избирательного права, меры по применению.

Научная специальность: 12.00.00 - юридические науки. 